\title{
POPPER'S PARADOX OF TOLERANCE: AN EXAMINATION OF SEGREGATED MUSLIM NEIGHBOURHOODS IN MODERN BRITAIN
}

\author{
RUMY HASAN*
}

University of Sussex

\begin{abstract}
The twenty first century has witnessed a heightened interest in Muslim settlers in western democracies. In Britain, following the suicide bombings of 9/11 and particularly in the aftermath of the 7th July 2005 bombings in London, much of this focus has been on the threat of terror attacks emanating from radicalised Muslims. It is clearly the case that the same focus also applies to other west European countries which have witnessed similar attacks. The question arises as to the kind of milieu in which domestic jihadist perpetrators have been raised and live. In most cases-though not all-an upbringing in segregated Muslim neighbourhoods is a recurring theme. These can be deemed 'closed communities', yet they are situated in open societies underpinned by a secular, liberal democratic polity. This paper provides reasons and evidence for the epithet of closed communities with respect to Muslims in Britain and explores how these-in many significant respects-differ from mainstream, liberal, secular society. The tensions that inevitably arise are considered together with their implications. The inspiration for this paper stems from Karl Popper's The Open Society and its Enemies.
\end{abstract}

KEY WORDS: Britain, Muslims, segregation, tolerance, Popper

\section{Introduction}

The twenty first century has witnessed a heightened interest in Muslim settlers in western democracies. In Britain, following the suicide bombings of 9/1 1 and particularly in the aftermath of the 7th July 2005 bombings in London, much of this focus has been on the threat of terror attacks emanating from radicalised Muslims. It is clearly the case that the same focus also applies to other west European countries which have witnessed similar attacks. There have been attempts by European governments and the EU to grapple with the phenomenon of what has come to be termed 'home grown' radicalisation which has, in some cases, precipitated acts of terrorism. The question arises as to the kind of milieu in which domestic jihadist perpetrators have been raised and live. In most cases — though not all-an upbringing in segregated Muslim neighbourhoods is a recurring theme.

* RUMY HASAN (DPhil 1994, University of Oxford) is a Senior Lecturer in the Science Policy Research Unit at the University of Sussex, United Kingdom, and Visiting Professorial Research Fellow at the Civitas think tank, London. 
Such Muslim segregated neighbourhoods can be deemed to a great extent to be 'closed communities'-yet they are situated in open societies underpinned by a secular, liberal democratic polity. This paper provides reasons and evidence for the epithet of closed communities with respect to Muslims in Britain and explores how these-in many significant respects-differ from mainstream, liberal, secular society. The tensions that inevitably arise are considered together with their implications.

The inspiration for this paper stems from Karl Popper's renowned The Open Society and its Enemies written during World War 2. For Popper, a closed society submits to 'magical forces' whereas an 'open society' sets free the critical powers of man. He warns that the transition from one to the other is one of the factors that have made possible the rise of those reactionary movements which have tried, and still try, to overthrow civilization and to return to tribalism' (Popper 2011 [1945]: xxxv).

Popper sought to understand the philosophical roots of the two main enemies of the open society at the time-Nazi Germany and Communist USSR. Though each other's mortal enemies, both were totalitarian police states and, ipso facto, were ideological enemies of the open societies of the west. Nazism's avowed aims were to crush the liberal democracies of Europe which, with the exception of Britain, it duly did between 1939 and 1942. By contrast, the Soviet Union was an ally of Britain and the USA, but it sought to obtain influence and, in the long term, engineer a transformation of these democracies into communist societies via control over domestic Communist Parties. Because Nazi Germany was decisively defeated whereas the USSR expanded its influence over several East European countries in the immediate aftermath of the war, Popper's main concern was the threat of communism to the liberal democratic order.

The closed Muslim communities that have arisen throughout Western Europe are not directly comparable to these two totalitarian ideologies and societies yet, on closer examination, the belief system espoused by the majority residing within them, offend against many of the freedoms taken for granted in open societies. And, insofar as some in their ranks avowedly challenge and fight against the host society-sometimes to the point of violence-they are necessarily enemies of the open society in which they inhabit. This being the case, Popper's dualism of open and closed societies is legitimate and valuable in the understanding of segregated Muslim communities in the west. Certainly, in their rigid adherence to Islamic precepts, they submit to 'magical forces' and this provides a fundamental bifurcation and attendant tensions and conflicts between them and the increasingly irreligious indigenous white population.

An open society is a tolerant society in the sense of having as its basis rational argument and reason. Dissent is tolerated, perhaps even encouraged, 
while differences on political matters are resolved through debate and democratic processes. The constitution and law provide arbitration and judgement where disputes arise-there is strictly no appeal to religious texts or priests. The state and society is tolerant of the right of people to freely practice their religion but, in the main, is intolerant of the encroachment of religious doctrines in democratic affairs, the constitution and the law. The extent of this varies, however, from country to country as some permit a number of exemptions to the law on religious and cultural grounds while others do not.

But a challenge to such a tolerant architecture has been mounted by the arrival of large number of non-European migrants to Europe in recent decades. Almost in their entirety, they understandably bring with them the whole gamut of beliefs and practices of their invariably authoritarian and highly religious homelands (see Hasan 2017). Indeed, Arthur Schlesinger (1998 [1991]: 133) makes the claim that Europe is the unique source of the ideas of individual liberty, political democracy, equality before the law, freedom of worship, human rights and cultural freedom. That other countries and regions have incorporated these into their societies and polities stems from the lead given by European countries (ibid). From this perspective, Fascism and Nazism, while hailing from Western Europe, can be considered as outliers; by contrast, Communism was never firmly established in Western Europe.

Many migrants tend to congregate in certain parts of towns and cities so there arises the gradual transformation of these areas into segregated areas dominated by a particular religious-ethnic grouping. Over time, the indigenous white population moves away-what has been termed 'white flight'resulting in the fomenting of pure religious-ethnic neighbourhoods. These are, in essence, closed communities. It is indubitably the case that in the past two decades, the phenomenon of segregated Muslim neighbourhoods has attracted the most attention and concern in Europe.

As we shall see in the survey evidence below, the weltanschaunng of Muslims in Britain is markedly less tolerant than that of the white population in many respects. The question naturally arises as to how the host society should respond to this-specifically, should it tolerate the less tolerant or intolerant settlers? Popper refers to the paradox of tolerance wherein he argues that:

... unlimited tolerance must lead to the disappearance of tolerance. If we extend unlimited tolerance even to those who are intolerant, if we are not prepared to defend a tolerant society against the onslaught of the intolerant, then the tolerant will be destroyed, and tolerance with them. In this formulation, I do not imply, for instance, that we should always suppress the utterance of intolerant philosophies: so long as we can counter them by rational argument and keep them in check by public opinion, suppression would certainly be most unwise. But we should claim the right to suppress them if necessary even by force; for it may easily turn out that they are not prepared to meet us on the level of rational argument, 
but begin by denouncing all argument; they may forbid their followers to listen to rational argument, because it is deceptive, and teach them to answer arguments by the use of their fists or pistols. We should therefore claim, in the name of tolerance, the right not to tolerate the intolerant (Popper 2011 [1945]: fn 4, 581).

The underlying tensions which, on occasion, spill over into conflict between an open, tolerant society and a closed, intolerant society is akin to Samuel Huntington's 'clash of civilisations' with the proviso that the clash occurs in the geographical space of the same town or city. In the aftermath of the Cold War, Huntington's thesis was that the fundamental antagonism among nations would be on the basis of 'civilisation' - taken to mean culture that encompasses language, history and religion-rather than political ideology or geopolitical considerations. Conflict would likely arise at the intersection of eight civilisations: Sinic [Chinese], Japanese, Hindu, Islamic, Orthodox, Western, Latin American, and African (Huntington 1997 [1996]: 45-47).

Huntington's book was published five years before $9 / 11$ but his focus on clashes between Islamic and Western civilisations gained popularity in the immediate aftermath. However, given the close alliance between western countries-especially the USA-and Sunni Arab countries, including Saudi Arabia with the two most important cities in Islam, the clash of civilisation thesis was inappropriate. Indeed, with the exception of Shia Iran and Syria, the west's relationship with Muslim-majority countries is rather benign and, at the present juncture, largely devoid of clashes.

By contrast, within western countries, clashes-or tensions and sharp disagreements-are palpable between Muslims and non-Muslims. In Britain, this is especially so between Muslims and Hindus and Sikhs but this has much to do with their origins in the Indian sub-continent and the continuing fallout of partition; the religious and national identities that ensued are still adhered by many to a significant extent. A striking example of this is the cancellation of a Sikh-Muslim interfaith event at a mosque in Birmingham in April 2019 whose aim it was to explain Vaisakhi and its importance to the Sikh community to local Muslims. However, intimidation by Sikh men against one of the organisers (also a Sikh man) with the threat of large numbers of protestors turning up at the mosque concerned, forced the cancellation of the event. Sikh Youth UK issued the following telling statement: 'The anti panthic event Vaisakhi in the Mosque has been cancelled, well done to all those who came together to address this in a constructive way, may the Panth [the moral and spiritual code established by the Sikh gurus] continue to flourish and take a stand against such anti panthic events' (Barfi Culture 2019). This highlights the widespread antipathy and much intolerance between Muslims and Sikhs in Britain.

However, the tensions and clashes that are prevalent between indigenous white populations and Muslims in many towns and cities are value-based and 
stem from the unease felt by the former to the very different and intolerant culture of the latter.

Such clashes can be tempered in two overarching ways: first, by the open society granting various separate laws and exemptions to laws-in effect, legal privileges - to the closed communities within its ranks. The example of the Amish in the US approximates to this. Second, by a programme of social engineering that seeks to integrate the closed settler community into mainstream society. This necessarily precludes legal privileges and group rights and asserts the universality of the law and constitution.

In Britain, no matter the government, there has been little attempt at systematic integration of Muslim settlers. Rather, under the rubric of a multicultural society, exemptions to the law where demanded by Muslims, have been granted. Not surprisingly, in the main, Muslims and indeed other religious groups, have opted to choose not to meaningfully integrate into mainstream society but instead to tenaciously cling on to the religious and cultural accoutrements of their countries of origin. Thus, a Kashmiri in Bradford has much more in common with a Kashmiri in Pakistan than with white Bradfordians. Given this reality, the moniker of 'Bradistan' to describe parts of Bradford has some justification.

Closed communities excel at fomenting and nurturing separate identities. But this has not been deemed problematic by national or local governments - as such, there has been an extraordinary neglect at integration and building a socially cohesive society so that social engineering is either thought of as an alien concept and practice, or is disdainfully ignored. This has resulted in, by default, a laissez faire approach which has ineluctably led to the festering of tensions arising from the taking root of segregated neighbourhoods. Hence, the open society has within its ranks an increasing number of closed communities.

This reality sheds a different light on the 'home-grown' phenomenon referred to earlier. It refers to someone being born and bred in a particular country or region-for our purposes Britain and Europe. It implies some meaningful commonalities between people. But being born and bred in a strict Muslim family and community is a far cry from being born and bred in an indigenous white family and community. Thus, a devout Muslim male teenager from Manningham in Bradford leads a profoundly different life to that of a white male teenager in a different part of the city. He attempts to pray five times a day, goes to the mosque every Friday, may receive Koranic instruction at a madrassah; out of school, he dresses in Islamic attire, does not drink alcohol, does not frequent pubs or clubs, nor go to beach resorts in the Mediterranean, does not have a girlfriend, and does not eat in cafes and restaurants that do not serve halal food. He will attend a school comprised 
mainly of Muslim pupils and will not likely have non-Muslim friends. In other words, he is a product of a closed Muslim community in the west.

By contrast, the white Bradfordian teenager will be highly irreligious, very rarely attending a church and then perhaps only for weddings rather than for prayer and worship; indeed the church will be an alien construct. All the activities that are avoided by the Muslim teenager or are a taboo are entirely normal to the white teenager-indeed they are key manifestations of modern teenage life.

\section{Survey Evidence of Muslim Views}

Evidence for the stark divergence between Muslim and mainstream views on various societal indicators has been accumulating over many years. Here we provide evidence from an extensive survey that was conducted in 2015 by the polling organisation ICM and formed the basis of a Channel 4 documentary What British Muslims Really Think presented by Trevor Phillips and aired on $13^{\text {th }}$ April 2016. ICM and Channel 4 state that 'Unlike many other surveys of Muslim opinion, which have predominantly been done by phone or online, ICM used face-to-face, in-home research to question a representative sample of 1,000 Muslims across Great Britain. ICM also used a 'control sample' to compare what British Muslims thought with the rest of the British population' (ICM and Channel 4, 2016). The summary of findings are:

At the top-line level, the survey suggests that a mainstream British Muslim majority have similar values and attitudes to the wider British public on issues such as support for British institutions and a feeling of belonging to Britain.

But looking deeper into the results, a chasm develops between those Muslims surveyed and the wider population on attitudes to liberal values on issues such as gender equality, homosexuality and issues relating to freedom of expression. And it also reveals significant differences on attitudes to violence and terrorism (ICM and Channel 4, 2016).

The major findings are as follows (Channel 4, 2016; see ICM 2016 for the full survey):

Mixing with non-Muslims

$56 \%$ mix with non-Muslims on a daily basis outside home (at work, in shops etc.)

$21 \%$ visit non-Muslim home once p.a.

$21 \%$ never visit non-Muslim home

An inevitable consequence of closed, segregated communities is that there is little need to mix with those from other outside the community; moreover, 
there is often little desire to do so. Where mixing or having contacts with nonMuslim 'others' does take place, it can be at a very superficial level and so devoid of genuine friendships. Certainly, from a very young age, there is enormous pressure to conform to the religion and culture and 'marrying out' of the religious-ethnic community is invariably a strict taboo. For many young girls and women, such breaches can lead to 'honour killings'.

\section{Women}

$39 \%$ believe that women should always obey their husbands $(45 \%$ for males; $33 \%$ for females; there is no difference in age groups) (9\% for nonMuslims).

\section{Polygamy}

$31 \%$ approve (35\% for $18-34$ year olds) of having more than 1 wife $(9 \%$ for non-Muslims).

\section{Homosexuality}

$18 \%$ think it should be legal (28\% for $18-24 \mathrm{~s}$; $2 \%$ for over $65 \mathrm{~s}$ ) (73\% for non-Muslims); $52 \%$ wish it to be outlawed (9\% for non-Muslims).

$47 \%$ do not believe that it is acceptable for a school teacher to be homosexual (25\% for non-Muslims).

What is striking in regard to attitudes towards women and homosexuality is the fact that the younger generation-almost in its entirety born in Britainholds traditional, reactionary, views skin to the older generations who are likely to have been born and brought up in Muslim majority countries. As such, their views accord more with the countries of their parents or grandparents than with their fellow non-Muslim, especially white majority, citizens.

\section{Freedom of Expression}

$78 \%$ say there should be no right to show pictures of the prophet. $87 \%$ say there should be no right to make fun of the prophet.

Muslims, in general, have never accepted freedom of expression, especially the freedom to criticise or lampoon Islam. This goes back to the colonial era in 1938 when protests in London were mounted by Muslims against H. G. Wells for his book Short History of the World in which he made a strong denunciation of the prophet Mohammed (Hasan 2016: 214). More famously, following Ayatollah Khomeini's fatwa in 1989, there were sustained and often violent protests against Salman Rushdie and his Satanic Verses (see Cliteur 2019: chs. 5 and 6). 
Adultery

$66 \%$ would completely condemn the stoning of an adulterer (61\% for $18-24$ year olds) (100\% for non-Muslims) i.e. one third of Muslims would not completely condemn the stoning of an adulterer.

\section{Separate Islamic life}

$17 \%$ wish to lead a separate life as far as possible

$23 \%$ support Sharia law in parts of UK

$45 \%$ prefer to send their child to school with strong Muslim values

These survey findings are unsurprising as they are a corollary to the manifestation of segregated Muslim communities. Inevitably, the closed thinking and lifestyle is bequeathed to the younger generations and so it is natural that almost half desire their children to attend schools with a strong Islamic ethos (this is discussed further in the next section). The survey found that those who sympathise with violence are twice as likely to live more separate lives and hold illiberal views on women's equality and gay rights.

\section{Attitudes to violence}

$34 \%$ would inform the police if they thought somebody they knew was getting involved with people who support terrorism in Syria

$4 \%$ sympathise with people who take part in suicide bombings

$4 \%$ sympathise with people who commit terrorist actions as a form of political protest

$32 \%$ refuse to condemn those who take part in violence against those who mock the Prophet

$18 \%$ approve of violence against those who mock the prophet

These figures highlight the fact that intolerant beliefs may elicit support for violent acts. Though only a small percentage sympathise with suicide bombing or terrorist acts (which are illegal), the actual numbers are worryingly high. Moreover, some within this grouping might themselves be willing to engage-or encourage others-in suicide bombings and acts of terror. As such, this presents a burdensome security challenge. The intolerance towards freedom of expression manifests in almost a third refusing to condemn violence against those who are deemed to have mocked the Prophet, with almost a fifth approving of such violence. These are disturbingly high figures but even more worrying is that some within the latter grouping may be prepared to carry out acts of violence against those whom they perceive to have maligned the Prophet. 
Trevor Phillips provided the following poignant summary:

Hearing what British Muslims themselves think, rather than listening to those purporting to speak on their behalf, is critical if we are to prevent the establishment of a nation within our nation. Many of the results will be troubling to Muslims and non-Muslims alike-and the analysis of the age profile shows us that the social attitudes revealed are unlikely to change quickly.

The integration of Britain's Muslims will probably be the hardest task we've ever faced. It will require the abandonment of the milk-and-water multiculturalism still so beloved of many, and the adoption of a far more muscular approach to integration (Channel 4, 2016).

\section{The Example of Segregated Muslim Majority Schools in Birmingham}

Birmingham is the second largest city in the UK with a large Muslim population hailing predominantly from Pakistan and Bangladesh. Since their arrival in the city post-World War 2, especially since the 1960s, Muslims have congregated heavily in the eastern parts of the city, so that many wards are now almost entirely comprised of Muslims. This is one of many examples in Britain of not only 'white flight' but the flight of other religious-ethnic minority groups from many neighbourhoods in all the major towns and cities. Under the rubric of multiculturalism and multifaithism, the right to practice one's faith is unimpeded, certain exemptions to the law, and allocation of resources by the national government and local authorities are provided so as to enable the nurturing of an Islamic lifestyle and identity - to the neglect of integration. It is, therefore, not at all surprising that members of the Muslim community in their majority, live in a manner more akin to their countries and regions of origin. This has inevitably led to tensions and clashes with the modus vivendi of mainstream society. Three recent examples of this in Birmingham are provided and are salutary in highlighting the nature of the open society and closed communities therein.

The first example stems from 2012-14 and concerns an attempt by Muslim extremists in Birmingham to take over the running of state schools according to Islamic principles-this became known as the 'Trojan Horse plot'. Note that though Muslim faith schools exist in Britain, the targeted schools were state non-faith schools that must observe the secular laws of the land. By contrast, schools granted the status of 'faith' school are allowed to teach a curriculum in accordance with the precepts of their religion.

The then Education Secretary Nicky Morgan commissioned an official inquiry into a number of Muslim majority schools in Birmingham led by the former anti-terror chief Peter Clark who provided a report in July 2014. Clark summarises his findings thus: 
'In summary, there has been a determined effort to gain control of governing bodies at a small number of schools by people who are associated with each other. Once in a position to do so, they have sought to introduce a distinct set of Islamic behaviours and religious practices. There is a disconcerting pattern reaching across a number of the schools I have looked at'.

Among various facts that Clark provides are the following:

- the effective take-over of the governing body by like-minded people; bullying and intimidation of senior teaching staff, and in particular headteachers;

- $\quad$ previously highly regarded headteachers made subject to criticism and interference by the governing body in the curriculum and the day-today running of the school;

- the reinforcement of Muslim identity to the exclusion or disparagement of others;

- the introduction of conservative Islamic practices into school life; a strategy of harassment to oust the headteacher; financial mismanagement; and inappropriate recruitment and promotion procedures for favoured staff. (emphasis added by $\mathrm{RH}$ ).

Clark points out that though 'not all of these features were present at every school, they occurred with sufficient regularity to warrant a detailed examination' (Clark 2014: 10-11). The report provides the following revealing practices:

In a number of schools RE [religious education] has become a central core subject ... Only modules in Islam are studied from Years 9 to 11 . The five students at Golden Hillock who opted to study the Christianity paper at GCSE sit separately in RE classes and teach themselves. In the primary schools that have been inspected by Ofsted, RE is taught largely from the Islamic perspective.

At Park View and other schools, governors have over-stepped their responsibilities by restricting schemes of work and insisting on an Islamic approach to such subjects as PSHE [personal, social, health and economic education], science, RE and SRE [sex and religious education]. Park View students speak openly about the fact that boys and girls should not study certain matters together. In biology GCSE, Year 11 students had been told to study the reproduction topic at home. Evolution is mentioned only briefly and students are simply directed to the page in the textbook. A teacher who did this went on to tell students that they were looking at the textbook merely to comply with the syllabus but that 'that was not what they believed' (Clark 2014: 36).

Muslim children have been taken to Saudi Arabia as part of a school trip paid for in part by school funds... Days were spent in Jeddah, Medina and Mecca (only Muslims may visit the latter two) (Clark 2014: 39).

Friday prayers have been introduced at a number of schools. Their part in the central life of the school is growing, as is the pressure on students and 
staff to attend. We have been told by staff at Park View that a tannoy to broadcast the 'adhan', the Muslim call to prayer, was installed. It could not only be heard across the whole school site, but also by residents in the local community, and was used every day to call students and staff to prayer ... Christmas was banned by governors at Nansen Primary in December 2013 (Clark 2014: $42,43)$.

This investigation has revealed a sustained and coordinated agenda to impose upon children in a number of Birmingham schools the segregationist attitudes and practices of a hardline and politicised strand of Sunni Islam. Left unchecked, it would confine school children within an intolerant, inward-looking monoculture that would severely inhibit their participation in the life of modern Britain (Clark 2014: 48) (emphasis mine).

The second example concerns Parkfield Community School in Alum Rock, Birmingham. Like the areas of the city of the schools investigated in the Clark Report, this is a highly segregated district where almost the entire population is Muslim which is reflected in the fact that 98 per cent of the pupils (aged between 4 and 11) in this school have Muslim parents. Controversy at the school arose in January 2019 over the school's 'No Outsiders' programme that was designed to teach pupils about LBGT sexuality and gender equality in accordance with the Equality Act 2010 and British values so as to prepare them for a life in modern Britain and 'create a positive school ethos where everyone feels they belong' (Kirby 2019).

But the programme aroused great hostility from the parents leading over 300 of them to sign a petition urging the school to drop the lessons from the curriculum. Weekly protests were organised outside the school with parents complaining that the No Outsiders programme was promoting gay and transgender lifestyles hence provoking them to remove their children from the school. But inspectors backed the school stating that there was "no evidence' that the curriculum 'focuses disproportionately on lesbian, gay, and bisexual issues and this work is taught in an age-inappropriate manner' (ibid). However, under pressure, the school suspended the programme stating that there was a need for discussions between teachers and parents about the curriculum and how it should be delivered in the future (BBC News, 5 th March 2019).

A leading member of the campaign against the No Outsiders programme, Amir Ahmed, argued that 'Fundamentally the issue we have with No Outsiders is that it is changing our children's moral position on family values on sexuality and we are a traditional community. Morally we do not accept homosexuality as a valid sexual relationship to have. It's not about being homophobic... that's like saying, if you don't believe in Islam, you're Islamophobic' (BBC News, 19th March 2019). 
Ahmed was being disingenuous-his community's moral rejection of homosexuality stems from the fact that it is prohibited in Islam, and that as devout believers the strictures of Islam necessarily trump those of 'British values' and of the secular laws of the land in which they reside. What he and the other Muslim parents were demanding is that the school-and the education authorities-grant them an exemption from the curriculum as it pertains to certain elements of the Equality Act. In other words, that the Muslim community should retain the right to hold and practice intolerant beliefs in accordance with their religion and in breach of the law.

Following the example of Parkfield School, Muslim parents from other schools not only in Birmingham but also in Manchester also protested against the teaching of LGBT issues and threatened to remove their children from sex and relationship lessons because they did not wish them to be taught about same-sex couples (BBC News 29th March 2019).

The third example concerns the Al-Hijrah Islamic faith school in Bordesley Green, another part of Birmingham with a highly segregated Muslim population. In October 2017, the school was found guilty of gender discrimination by the Court of Appeal. The Chief Inspector of Schools, Amanda Spielman, pointed out that 'The school is teaching boys and girls entirely separately, making them walk down separate corridors, and keeping them apart at all times... This is discrimination and is wrong. It places these boys and girls at a disadvantage for life beyond the classroom and the workplace, and fails to prepare them for life in modern Britain' (BBC News, 13th October 2017).

But in January 2019, Luke Tryl, director of corporate strategy at Ofsted, the inspectorate for schools in England, stated at the Women and Equalities Select Committee of parliament that Al-Hijrah school was still segregating boys and girls:

'Our inspectors are going out and having to make some quite tricky judgements where there are those potential clashes [between equalities laws and religious freedoms] ... We perhaps don't always feel we get the support we need from the rest of Government in pushing that forward.' He said that Al-Hijrah school was enforcing a 'very strict gender segregation' which included 'denying the girls to have their lunch until the boys had had theirs'. 'And we had some very discriminatory texts for instance, encouraging violence against women’ (Turner 2019).

Mr Tryl pointed out that it was not just Al-Hijrah but countless other schools, mixed schools, which are segregating on the basis of sex. He drew a forceful conclusion: 'This is where I talk about the isolation. We go out there. We make these tough decisions and we often take quite a lot of criticism for the stance we take but we don't always see the enforcement action we would like to see' (Turner 2019). 
The tensions between equalities laws and religious freedoms are now playing out not only in neighbourhoods and schools therein with large numbers of Muslims across Britain but these tensions go beyond schools and permeate throughout society. The lack of support provided by the government to school inspectors highlighted by Luke Tryl is significant and demonstrates that the supposed defenders of the open society and attendant rights and freedoms are often timid in the face of fierce opposition from the Muslim community and indeed from other religious-ethnic minority communities; they thereby fail to assert the core values of their society-and by this reticence these begin to be eroded.

\section{Heightened Segregation and Lack of Integration}

Data broken down by religious affiliation is not adequately collated but people of Bangladeshi and Pakistani backgrounds-which comprise two of the largest ethnic minority groups-are overwhelmingly Muslim. The 2011 census showed that there were 2.8 million Muslims in the UK, amounting to 4.4 per cent of the population. By the next census in 2021, this will be well in excess of 3 million and above 5 per cent of the population. Islam is the second largest religion after Christianity. Muslims tend to live in more residentially segregated areas than other ethnic groups in Britain; moreover, segregation has increased over the years. This is highlighted in the Casey Review on Opportunity and Integration commissioned by the former Prime Minister David Cameron in 2015 (conducted by Dame Louise Casey):

People of Pakistani and Bangladeshi ethnicity tend to live in more residentially segregated communities than other ethnic minority groups. South Asian communities (people of Pakistani, Indian and Bangladeshi ethnicity) live in higher concentrations at ward level than any other ethnic minority group. These concentrations at ward level are growing in many areas. In 2011 there were:

- 24 wards in 12 local authority areas where more than $40 \%$ of the population identified themselves as being of Pakistani ethnicity; up from 12 wards in 7 local authorities in 2001;

- Compared to other minority faith groups, Muslims tend to live in higher residential concentrations at ward level;

- In 2011, Blackburn, Birmingham, Burnley and Bradford included wards with between $70 \%$ and $85 \%$ Muslim populations.

Casey points out that "the school age population is even more segregated when compared to residential patterns of living. A Demos study found that, in 2013 , more than $50 \%$ of ethnic minority students were in schools where 
ethnic minorities were the majority, and that school segregation was highest among students from Pakistani and Bangladeshi ethnic backgrounds relative to other ethnic groups' (Casey Review 2016: 10-11).

Integration has been slow and hampered by what Casey terms high levels of transnational marriage where 'subsequent generations are being joined by a foreign-born partner, creating a 'first generation in every generation' phenomenon in which each new generation grows up with a foreign-born parent [with poor or non-existent knowledge of the English language]. This seems particularly prevalent in South Asian communities ... A study by Bristol University found that half of British Pakistanis married back in Pakistan, and that most of these marriages were between cousins or other members of extended kin groups' (Case review 2016: 9, 32).

Indeed, the aim of fundamentalist Muslims is the outright rejection of western society—a point stressed in a 2004 study by the Dutch General Intelligence and Security Services (AIVD):

In particular Dawa-oriented radical-Salafist organisations and networks from Pakistan, Saudi Arabia and the Arab Gulf states strongly emphasise 're-Islamisation' of the Muslim minorities in the West. These organisations include missionary, socio-cultural and finance organisations which claim not to be politically orientated or violent, but whose activities are often based upon extreme puritan, intolerant and strongly anti-Western ideas. Their efforts are purposefully aimed at encouraging Muslims in the West to turn their back on Western values and standards. They preach an extreme isolationism from Western society and propagate 'exclusivism' and parallelism (AIVD 2004: 27).

The Casey Review stressed the fact that the lack of integration, especially of Muslims in Britain, was problematic - ipso facto this was an admission of the lack of effort to this effect by national governments and by local authorities. The reality is that - and given succour by the policies engendered in multiculturalism-ethnic and religious minorities can lead lives akin to those of their countries of origin. In regard to Islam, pretty much the entirety of the requirements of the religion are allowed: mosques, madrasas, halal food provision in schools and public and private institutions (despite the Farm Animal Welfare Council-the government's scientific advisers on animal welfarecalling for the outlawing of religious slaughter of animals [FAWC 2003: Recommendation 201,60]), toleration of veiling of women (burkas, jilbabs, and hijabs are commonplace), and of Muslim attire in general, acceding to restrictions on freedom of expression, etc. It is, therefore, not surprising that the ICM/Channel 4 survey found that $94 \%$ of Muslims thought that they are able to practice their religion freely in Britain (ICM, 2016). But, truly unsavoury practices have also been imported into the country including female genital mutilation, forced marriage, and honour killings and honour-based 
violence-though the former two are now outlawed, they nevertheless continue to take place.

\section{Social and Political Consequences}

Unease and Hostility towards Islam and Muslims

The indulgence of Muslims and the failure to integrate them has indubitably alienated the indigenous white society and has been a factor in 'white flight' remarked on earlier - and indeed the flight of other religious-ethnic minorities from neighbourhoods where Muslims have settled in large numbers. Hence, the number and extent of closed Muslim communities continues to increase at an accelerating pace.

Accordingly, there has been increasing unease with the Muslim presence in Britain (and the same applies throughout Europe). This is clearly evidenced, for example, in a major survey (What Do Europeans Think about Muslim Immigration?) conducted by the Chatham House think-tank in 10 European countries between December 2016 and January 2017 (the countries are Austria, Belgium, France, Germany, Greece, Hungary, Italy, Poland, Spain, and United Kingdom). The survey was based on the statement: 'All further migration from mainly Muslim countries should be stopped'. Overall, across all 10 countries an average of $55 \%$ agreed with this; for the UK, this was $47 \%$ agreed; $30 \%$ neither agreed nor disagreed and 23\% disagreed (Chatham House 2017).

Similarly, a Populus poll in 2011 - at the time the largest survey into identity and extremism in the UK-found that 52 per cent of respondents agreed with the proposition that 'Muslims create problems in the UK' (a far higher percentage than for other religious groups) (Populus, 2011). Two opinion polls separately conducted in 2015 found that only $22 \%$ of the non-Muslim population think that the values of Islam are compatible with the values of British society; by contrast, in both polls more than half thought they are not compatible (Survation 2015; YouGov 2015). The Survation poll found that $57 \%$ of non-Muslims thought that British Muslims were not doing enough to integrate into British society.

\section{Women in Closed Muslim Communities}

The Casey Review highlighted the problems that women within segregated religious-ethnic minority communities experience (this applies particularly to Muslim women). This is succinctly summarised as:

$[\mathrm{H}]$ igh levels of social and economic isolation in some places and cultural and religious practices in communities that are not only holding some of our citizens back but run contrary to British values and sometimes our laws. Time and time again I found it was women and children who were the targets of these regressive 
practices. And too often, leaders and institutions were not doing enough to stand up against them and protect those who were vulnerable (Casey 2016: 5).

Women in some communities are facing a double onslaught of gender inequality, combined with religious, cultural and social barriers preventing them from accessing even their basic rights as British residents. And violence against women remains all too prevalent - in domestic abuse but also in other criminal practices such as female genital mutilation, forced marriage and socalled 'honour' based crime (Casey 2016: 14).

... discriminatory practices against women which, in some cases, are causing serious harm. Some women's rights groups have accused Sharia Councils and other parallel legal systems of denying vulnerable women and children access to equality and human rights. There have been claims that some Sharia Councils have been supporting the values of extremists, condoning wife-beating, ignoring marital rape and allowing forced marriage (Casey 2016: 132-133).

Machteld Zee (2016) provides an in-depth survey of the workings and discriminatory judgments of Sharia Councils in Birmingham and London. These disturbing facts affirm the claim made above about the ability of Muslims, should they so choose, to lead lives in Britain in a manner akin to their countries of origin where women have invariably less rights often to the extent of being, de facto, second-class citizens. It should be noted that although Sharia Councils are not granted legal jurisdiction, the very fact that they are allowed to operate-and mete out discriminatory judgements to women-is an indicator of the multifaith mindset that has taken root.

Casey's finding that women in segregated Muslim communities are unable to access 'even their basic rights as British residents' is a manifestation of the rank failure of integration and hence an indictment of the authorities.

\section{Prevalence of Islamist Terrorists from Segregated Muslim Areas}

A major survey of Islamist terrorism from 1998-2015 by Hannah Stuart of the Henry Jackson Society found that terrorists tended to hail from areas with large Muslim populations and concentrated in three regions. Thus, almost half (43\%) of Islam Related Offences [IROs] were conducted by residents of London. East London was home to half (50\%) of London-based offenders, while the three most common boroughs-Tower Hamlets, Newham and Waltham Forest-contained the offenders' residence in $38 \%$ of all Londoner IROs (and 16\% overall). The city with the second highest offences with $14 \%$ of IROs was Birmingham while the third most common region was North West England, with 10\%. Birmingham residences were more concentrated in a smaller number of wards and constituencies than those in London, which were spread across a higher number of boroughs and sub-regions. The 
constituencies of Hall Green and Hodge Hill contained almost three-quarters (74\%) of Birmingham cases (Stuart 2017: ix).

In total, these three regions accounted for almost three-quarters (72\%) of cases. Based on religious identity data collected in the 2011 census, individuals who committed IROs were more likely than the national Muslim average to be living in neighbourhoods where the Muslim proportion of the population was $20 \%$ or above.

While these findings are enlightening, they are unsurprising given that closed Muslim communities can nurture a strict Islamic ethos which, in extremis, can be a progenitor of jihadism. They accord with the Casey Review's finding of 'a growing sense of grievance among sections of the Muslim population, and a stronger sense of identification with the plight of the 'Ummah', or global Muslim community' (Casey Review 2016: 13).

The role and influence of imams (and other community 'leaders' and 'elders') is often profound as they are the moral guardians of their neighbourhoods. If he is so inclined, an imam can make recourse to extracts of the Koran and the hadith to foment victimhood on his flock and subtly raise the banner of jihad. The habitus of the close-knit, segregated Muslim community is conducive to such a scenario and facilitates the taking root of the most intolerant and indeed violent ideas in a liberal democracy.

\section{Grooming of White Girls by Muslim Men}

The fact of closed Muslims communities does not preclude interaction with non-Muslim communities surrounding them, but such interactions are not necessarily positive-indeed they can be highly problematic. This is precisely the case in regard to the most troubling phenomenon of 'grooming' of white girls and child sexual exploitation (CSE) by gangs of men who are almost in their entirety Muslim. Towns and cities that have experienced CSE include Aylesbury, Banbury, Bristol, Derby, Halifax, Keighley, Newcastle, Oxford, Peterborough, Rochdale, Rotherham, and Telford. Indeed, Ann Coffey MP, author of a report on CSE in Rochdale, concluded that the phenomenon had become a 'social norm' in Greater Manchester (Coffey, 2014). Alexis Jay, author of a report on CSE in the Yorkshire town of Rotherham stated that 'Our conservative estimate is that approximately 1400 children were sexually exploited over the full Inquiry period, from 1997 to 2013' (Jay, 2014). Jay summarises her findings as follows:

It is hard to describe the appalling nature of the abuse that child victims suffered. They were raped by multiple perpetrators, trafficked to other towns and cities in the north of England, abducted, beaten, and intimidated. There were examples of children who had been doused in petrol and threatened with being set alight, threatened with guns, made to witness brutally violent rapes and threatened they 
would be next if they told anyone. Girls as young as 11 were raped by large numbers of male perpetrators. [...]

By far the majority of perpetrators were described as 'Asian' by victims, yet throughout the entire period, councillors did not engage directly with the Pakistani-heritage community to discuss how best they could jointly address the issue. Some councillors seemed to think it was a one-off problem, which they hoped would go away. Several staff described their nervousness about identifying the ethnic origins of perpetrators for fear of being thought racist; others remembered clear direction from their managers not to do so (Jay 2014: 1, 2).

Jay drew attention to the fact that a report on child sexual exploitation in Rotherham was submitted as far back as 2002 yet no action was taken. She states forthrightly: 'Had this [2002 draft] report been treated with the seriousness it merited at the time by both the police and the council, the children involved then and later would have been better protected and abusers brought to justice' (BBC News 2015).

It is important to note that almost all the victims in Rotherham and in other towns and cities of grooming and CSE were white girls, invariably under 16 years of age. As such, these were systematic racist acts by non-white Muslim men. But calling attention to this stark fact was a taboo for the authorities; a manifestation of political correctness so rife in the country. It was not just councillors who were fearful of being labelled as racist and indeed Islamophobic if they pointed to this elephant in the room but other public services too, notably the police and social services. Furthermore, this same thinking applied to the media writ large who for years shied away from investigating and uncovering the perpetrators of these horrific crimes-a case of self-censorship and, as such, a dereliction of duty. This was a catastrophic failing on the part of the guardians of the liberal, tolerant society in the face of grotesque, intolerant, acts unleashed on an industrial scale by Muslim men for decades against minors.

\section{Political Cnsequences}

An important fact of political importance is that grooming and child sexual exploitation is prevalent in parts of towns and cities where the Labour Party is dominant. Here it needs stressing that Labour has been especially keen to maintain its support among the Muslim community, and has a long history of accommodating the demands made by its self-styled 'leaders', and indeed of leaders of other ethnic minority communities. The Runnymede Trust estimates that Labour received about two-thirds of the BME (black and ethnic minority) vote in the 2017 general election (Runnymede Trust 2017).

At the 2017 general election, 85\% of Muslims voted Labour (British Religion in Numbers, 2017) and so the Labour Party does not wish to alienate 
this substantial voting bloc. The Muslim Engagement and Development group (MEND) estimates that 83 constituencies (13\% of the total) have more than $10 \%$ or more of Muslim voters and so the Muslim vote can be decisive in the outcome. In the 2017 general election, in all 25 constituencies with the highest percentage of Muslim voters, Labour candidates were elected with a higher majority than in 2015 (MEND 2017).

Given this political and electoral reality, it is explicable why Labour Party officials and members writ large tend to refrain from criticising Muslims and Islam, including horrific acts such as child sexual exploitation. Revealingly, when the Labour MP for Rotherham Sarah Champion stated the truth about the ethnicity of the perpetrators, she was summarily removed from the Shadow Cabinet. In an article for the Sun newspaper in 2017, she wrote: 'Britain has a problem with British Pakistani men raping and exploiting white girls. There. I said it. Does that make me a racist? Or am I just prepared to call out this horrifying problem for what it is?' (Champion 2017). For such truth telling, Champion was not only chastised by her Labour Party colleagues but received no support from the other parties, including the governing Conservative Party; moreover, she received death threats and was provided with extra security (Sky News 2018).

The Casey Review's conclusion regarding political actors is relevant here and uncompromising: 'Too many public institutions, national and local, state and non-state, have gone so far to accommodate diversity and freedom of expression that they have ignored or even condoned regressive, divisive and harmful cultural and religious practices, for fear of being branded racist or Islamophobic' (Casey 2016: 16).

\section{Concluding Remarks}

Should an open, liberal society tolerate closed, illiberal communities in their midst, that is, allow 'a nation within a nation'? Karl Popper, as we have seen, answers firmly in the negative. The political philosopher John Rawls concurred with this standpoint in his A Theory of Justice arguing that in regard to religious toleration, under a just constitution, an intolerant sect has no title to complain if it is not tolerated (Rawls 1971: 217, 220). Yet, no matter the government, the burgeoning of closed, segregated religious-ethnic minority neighbourhoods has continued apace, none more so than Muslim. Popper's paradox of tolerance is being borne out as intolerant beliefs and practices of Muslim communities mount a challenge to the hard-won gains of a tolerant, liberal-democratic society across several fundamental areas: women, children, homosexuals, freedom of expression, and secularism being the most important.

Fearful of being labelled racist or Islamophobic, the authorities-be they national or local-have barely resisted this challenge. Rather, they have 
invariably relented under the pressure of the intolerant, illiberal attitudes of Muslims and, by so doing, displayed 'reverse racism' whereby Muslims (and indeed other religious-ethnic minorities) are granted privileges, including legal exemptions, and continuous sensitivity and empathy. This certainly gives the tacit impression that the tolerant, liberal-democratic order is the preserve of the indigenous white society whose rules and values do not fully apply to religious-ethnic minorities-the ideological underpinnings of this de facto racist stance are cultural and moral relativism.

Even for acts outlawed-female genital mutilation (FGM) and forced marriage-there has been an absence of robust initiatives and attendant measures to root these out from society. The first successful prosecution for FGM took place as late as 2019, an astonishing 34 years after the law outlawing the practice was passed (Summers and Ratcliffe 2019). A 2015 study estimated that there were 137.000 women and girls who had been subjected to FGM in England and Wales (Macfarlane and Dorkenoo 2015). Forced marriage was only made (partially) illegal in 2007 (under the Forced Marriage (Civil Protection Act 2007) even though existence of the practice was widely known soon after the arrival of migrants from South Asia. The Anti-Social Behaviour, Crime, and Policing Act of 2014 makes forced marriage (including to someone from another country) a criminal offence. Importantly, there is still no law specifically relating to honour killings and honour-based violence.

The widespread opposition to further Muslim immigration highlighted in the Chatham House survey cited above is a clear reflection of the indigenous white society's disliking of its impact on society, above all of the various intolerant beliefs and practices. This is indirectly attested by the British Social Attitudes 2014 Edition survey which found that almost a fifth (18\%) of the population thought that British cultural life was strongly undermined by immigration, and a further $27 \%$ thought it was undermined (hence, $45 \%$ held a negative view of immigration in regard to its cultural impact). By contrast, only $6 \%$ thought it was strongly enriched by immigration and a further $29 \%$ thought it was enriched by immigration (hence, $35 \%$ held a positive view of the cultural impact of immigration) (BSA 2014: 82, table 5.3). Therefore, considerably more thought the cultural impact of immigration negatively than those who viewed it positively with the implication that British national identity has been undermined by mass immigration.

Though the BSA survey does not provide the data, it would be reasonable to infer that the percentages in regard to Muslim immigration would be even worse. This reasoning stems from the fact that little more than a fifth of nonMuslims think that Islam is compatible with British values (as evidenced in the Survation and YouGov surveys) suggesting that perhaps as many as twothirds of the population think that the Muslim presence has had a negative influence on the national culture. 
Given that large numbers of Muslims have settled in and are continuing to settle in Britain, and given that the Muslim population is rising rapidly, the problems emanating from closed Muslim communities highlighted in this chapter will mount. To reverse this deepening problem, vigorous and sustained actions by state and non-state actors will need to be taken. The task is to bring the thinking and practice of those residing in such closed, segregated communities in line with those engendered in an open, tolerant, society.

So while Muslims and other religious-ethnic minorities can adhere to beliefs and practices that accord with their religion, these must not be accommodated by the granting of legal privileges. Just as Catholics may believe that abortion, divorce, and homosexuality are morally wrong, in western democratic societies, they largely accede to the secular law and societal norms which recognise these as legal and valid (though the evangelical Christians in the southern states of the USA have never accepted the legitimacy of the law on abortion). Thus, illiberal beliefs may be held without a challenge to the law thereby accommodating to the tolerant society. Precisely the same outcome needs to be attained by Muslims in western societies.

\section{Bibliography}

AIVD [Dutch General Intelligence and Security Service] (2004) From Dawa to Jihad: The Various Threats from Radical Islam to the Democratic Legal Order. The Hague: AIVD, https://english.aivd.nl/publications/publications/2005/03/-30/from-dawa-to-jihad.

BBC News (2015) Rotherham abuse scandal: Key dates. 26th March, https://www.bbc.co.uk/news/uk-28955170.

BBC News (2017) Birmingham Islamic faith school guilty of sex discrimination. 13th October, https://www.bbc.co.uk/news/uk-england-birmingham-41609861.

BBC News (2019) LGBT lessons row: More Birmingham schools stop classes. 19th March, https://www.bbc.co.uk/news/uk-england-birmingham-47-040451 .

BBC News (2019) LGBT people 'never felt more vulnerable' in Birmingham. 29th March, https:/www.bbc.co.uk/news/uk-england-birmingham-47742085.

BBC News (2019) Parents protest over Birmingham school's LGBT equality teaching. 29th January, https://www.bbc.co.uk/news/uk-england-birmingham-47613578.

BBC News (2019) Parkfield Community School LGBT protests: School denies 'U-turn'. 5th March, https://www.bbc.co.uk/news/uk-england-birmingham-47452904. 
British Religion in Numbers (2017) Counting Religion in Britain. August, http://www.brin.ac.uk/religious-affiliation-and-party-choice-at-the-2017general-election/.

British Social Attitudes 31 (2014 Edition). London: NatCen Social Research, http://www.bsa.natcen.ac.uk/media/38893/bsa31_full_report.pdf.

The Casey Review: A Review into Opportunity and Integration (2016) Department for Communities and Local Government. December, https://assets.publishing.service.gov.uk/government/uploads/system/uploads/attachment_data/file/575973/The_Casey_Review_Report.pdf.

Channel 4 (2016) Documentary: What British Muslims Really Think. Aired on 13th April, https://www.youtube.com/watch?v=hpHE3_-3VEc.

Champion S (2017) British Pakistani men ARE raping and exploiting white girls... and it's time we faced up to it. 10th August, https://www.thesun.co.uk/news/4218648/british-pakistani-men-raping-exploitingwhite-girls/.

Chatham House (2017) What Do Europeans Think About Muslim Immigration? https://www.chathamhouse.org/expert/comment/what-do-europeans-think-about-muslim-immigration\# .

Clark P (2014) Report into allegations concerning Birmingham schools arising from the 'Trojan Horse' letter, House of Commons 576, Open Government License. July, https://assets.publishing.service.gov.uk/government/uploads/system/uploads/attachment_data/file/340528/HC_576_print_ready.pdf.

Cliteur P (2019) Theoterrorism versus Freedom of Speech: From Incident to Precedent. Amsterdam: Amsterdam University Press.

Coffey A (2014) Real voices: Coffey report on child sexual exploitation in Greater Manchester. November, https://www.lgiu.org.uk/wp-content/uploads/2014/1 1/Real-voices-Coffey-report-on-child-sexual-exploitation-inGreater-Manchester.pdf.

Farm Animal Welfare Council (FAWC) (2003) Report on the Welfare of Farmed Animals at Slaughter or Killing, Part 1: Red Meat Animals. http://www.fawc.org.uk/reports/pb8347.pdf.

Hasan R (2016) Blasphemy, multiculturalism and free Speech in modern Britain. In Cliteur P and Herrenberg T (eds) The Fall and Rise of Blasphemy Law. Leiden: Leiden University Press, pp. 209-233.

Hasan R (2017) Religion and Development in the Global South. New York, NY: Palgrave Macmillan.

Huntington S (1997) The Clash of Civilizations and the Remaking of the World Order. London: Simon and Schuster.

ICM (2016) Muslim Survey for Channel 4, https://www.icmunlimited.com/wp-content/uploads/2016/04/Mulims-full-suite-data-plus-topline.pdf. 
ICM and Channel 4 (2016) C4 survey and documentary reveals What British Muslims Really Think. https://www.channel4.com/press/news/c4-surveyand-documentary-reveals-what-british-muslims-really-think.

Jay A (2014) Independent Inquiry into Child Sexual Exploitation in Rotherham 1997-2013. https://www.rotherham.gov.uk/downloads/file/1407/-independent_inquiry_cse_in_rotherham.

Kirby D (2019) Birmingham primary school suspends LGBT lessons after protests. iNews, 15th March, https://inews.co.uk/news/education/education-schools-parkfield-primary-community-school-lgbt-lessons-teachersparents-protests/.

Macfarlane A and Dorkenoo E (2015) Prevalence of Female Genital Mutilation in England and Wales: National and Local Estimates. London: City University. https://www.city.ac.uk/_data/assets/pdf_file/0004/282388/FGM-statisticsfinal-report-21-07-15-released-text.pdf.

Muslim Engagement and Development [MEND] (2017) Power of the Muslim vote and Muslim voting patterns. https:/www.mend.org.uk/wp-content/uploads/2017/10/Power-of-the-Muslim-vote-and-Muslim-voting-patterns.pdf.

Popper K (2011 [1945]) The Open Society and its Enemies. Abingdon: Routledge. Populus (2011) Opinion poll on extremism and identity. http://www.populus.co.uk/wp-content/uploads/2015/12/download_pdf-310111-Searchlight-Fear-and-Hope-survey.pdf.

Rawls J (1971) A Theory of Justice. London and Cambridge MA: Belknap Press. Sky News (2018) Extra security for MP who said British Pakistani men are raping white girls. 25th July, https://news.sky.com/story/extra-security-formp-who-said-british-pakistani-men-are-raping-white-girls- 1448106.

Runnymede Trust (2017) Labour gets two-thirds of BME vote. 9th June, https://www.runnymedetrust.org/blog/labour-gets-two-thirds-of-bme-vote.

Stuart H (2017) Islamist Terrorism: Analysis of Offences and Attacks in the UK (1998-2015). London: Henry Jackson Society. http://henryjacksonsociety.org/wp-content/uploads/2017/03/Islamist-Terrorism-preview-1.pdf.

Schlesinger A (1998 [1991]) The Disuniting of America: Reflections on a Multicultural Society. New York, NY: W. W. Norton.

Summers H and Ratcliffe R (2019) Mother of three-year-old is first person convicted of FGM in UK. The Guardian, 1st February, https://www.-theguardian.com/society/2019/feb/01/fgm-mother-of-three-year-old-first-person-convicted-in-uk.

Survation (2015) British non-Muslims poll. https://survation.com/wp-content/uploads/2015/03/Full-Sky-non-Muslim-tables.pdf.

Turner C (2019) Muslim school will not allow girls to eat lunch until after boys have finished, Ofsted chief says. The Telegraph, 30th January, http- 
s:/www.telegraph.co.uk/education/2019/01/30/muslim-school-will-not-allow-girls-eat-lunch-boys-have-finished/.

Yougov (2015) Poll on attitudes to Islam. http://cdn.yougov.com/cumulus_uploads/document/ogqzisd2xq/Islam\%20and\%20British\%20values.pdf.

Zee M (2016) Choosing Sharia: Multiculturalism, Islamic Fundamentalism, and Sharia Councils. The Hague: Eleven International Publishing. 